\section{Budbreak and Winter Injury in Exotic Firs}

\author{
G.E. Jones \\ Department of Horticulture, Michigan State University, East Lansing, \\ MI 48824
}

\author{
B.M. Cregg ${ }^{1}$ \\ Department of Forestry, Michigan State University, East Lansing, MI 48824
}

Additional index words. cold hardiness, chlorophyll fluorescence, frost damage

\begin{abstract}
Seventeen Abies species were evaluated for budbreak and frost injury at four locations in Michigan. Freeze tests were conducted on four species growing at the Horticulture Teaching and Research Center to determine cold hardiness levels during winter. Species differed $(P \leq \mathbf{0 . 0 0 0 1})$ in their days to budbreak at all locations. Trees that had broken bud were more prone to late spring frost damage than trees yet to break bud. Species differed in chlorophyll fluorescence, bud damage, and needle damage after exposure to $-44^{\circ} \mathrm{C}$. Bud, foliar, and cambium damage were correlated with chlorophyll fluorescence following freeze tests. Budbreak and midwinter cold hardiness were correlated. Species breaking bud earlier displayed greater midwinter cold hardiness than species breaking bud later. Selection criteria for future Abies introductions to the upper midwestern U.S. should include identifying species with late budbreak to reduce risk of late frost injury.
\end{abstract}

Throughout the midwestern U.S., planting of conifers has been typically limited to a few species of trees. Trees such as douglas fir [Pseudotsuga menziesii (Mirbel.) Franco], norway spruce [Picea abies (L.) Karst.], colorado blue spruce [Picea pungens Englem.], scotch pine (Pinus sylvestris L.), austrian pine (Pinus nigra Arnold), and eastern white pine (Pinus strobus L.) are frequently used to the point of overplanting. The resulting lack of diversity has led to increased disease problems and insect pressures (McCullough et al., 1998). Recent efforts to increase conifer diversity have sparked increased interest in planting exotic conifers. Much of this interest has centered on exotic firs and their hybrids.

The use of Abies in the landscape and Christmas tree industries has been limited to a few species. Expanded use of Abies in landscapes has been limited by their perceived intolerance of many site conditions. However, Abies may be more tolerant of environmental conditions than originally thought as species differ in their response to soil $\mathrm{pH}$ (Cregg et al., 2004), drought (Guehl et al., 1991), and freezing temperatures (Sakai, 1982). Collectively, Abies cover large elevational and latitudinal ranges (Liu, 1971). Langlet (1963) suggests large species distribution ranges increase the likelihood of genetic adaptation to diverse environmental factors.

For future evergreen conifer introductions in the upper midwestern U.S., tolerance of freezing temperatures is a necessary charac-

\footnotetext{
Received for publication 5 Aug. 2005. Accepted for publication 7 Oct. 2005. We thank Alison Heins and Sara Tanis for their assistance recording budbreak information, Xuewen Huang for his statistical advice, the Michigan Agriculture Experiment Station Project GREEEN, Michigan Nursery and Landscape Association, and the Landscape Plant Development Center for providing funding for this project.

${ }^{1}$ To whom reprint requests should be addressed; e-mail cregg@msu.edu.
}

teristic. Trees with adequate cold hardiness are required as average winter low temperatures range from -20 to $-42{ }^{\circ} \mathrm{C}$ in the upper midwestern U.S. (USDA Plant Hardiness Zone Map, 1990). Also, species with late budbreak will have reduced damage from late spring frosts.

In conifers, cold hardiness levels increase in the late fall, reach a maximum in midwinter, and decrease as temperatures rise in late winter (Ritchie, 2003). In A. lasiocarpa (GordonKamm, 1980; van der Kamp and Worrall, 1990), A. procera (Owston and Kozlowski, 1981), and A. amabilis (Dougl.) Forbes (van der Kamp and Worrall, 1990) cold hardiness was reduced following periods of warm temperatures. Maximum cold hardiness also varies among species. For example, A. spectabilis (D.Don) Spach is cold hardy to $-25^{\circ} \mathrm{C}$ while A . balsamea and $A$. sibirica Ledeb. are cold hardy to $-70^{\circ} \mathrm{C}$ (Sakai, 1982). Considerable intraspecific variation has also been documented for provenances of $A$. grandis (Dougl.) Forbes (Xie and Ying, 1993) and A. sachalinensis (Fr. Schm.) Mast. (Eiga and Sakai, 1984). Provenance variation in cold hardiness may be related to latitude, elevation, and winter snowfall.

The direct effect of freezing temperatures is the failure of cell biological functions (Binder and Fielder, 1996; Yordanov, 1992) causing secondary limitation to the photoharvesting system (Adams and Perkins, 1993). Chlorophyll fluorescence is used to measure the efficiency by which photosystem II captures light and is often expressed as the ratio of variable fluorescence to maximum fluorescence $\left(\mathrm{F}_{\mathrm{v}} / \mathrm{F}_{\mathrm{m}}\right)$ (Bjorkman and Demming, 1987). Chlorophyll fluorescence is useful in quantifying cold hardiness (Adams and Perkins; 1993; Binder and Fielder, 1996).

Budbreak is under strong genetic control in A. amabilis and A. lasiocarpa (Worrall, 1983) and is an adaptive response to climate conditions at the population's origin in P. menziesii var. menziesii (Mirb.) Franc (Campbell and Sugano, 1979). First a chilling requirement and then a growing degree day (GDD) requirement must be satisfied for budbreak to occur (Campbell and Sugano, 1979; Howe et al., 2003). Northern provenances of Acer rubrum $\mathrm{L}$. have a longer chilling requirement than southern provenances (Perry and $\mathrm{Wu}$, 1960). Provenances from colder regions have a reduced GDD requirement for budbreak than provenances from warmer regions (Campbell and Sugano, 1979). For example, Picea mariana (Mill.) B.S.P. provenances from northern Canada broke bud $7 \mathrm{~d}$ earlier than provenances from the northern U.S. when grown in southern Ontario, Canada (Morgenstern, 1978).

Species that break bud earlier in the spring are more susceptible to late spring frosts than those breaking bud later in the spring (Hansen and Larsen, 2004; Leege, 2002). Timing of budbreak differs among provenances for A. alba Mill. (Hansen and Larsen, 2004), A. amabilis (Worrall, 1983), A. grandis (Scholz and Stephan, 1982), and A. lasiocarpa (Hansen et al., 2004; Worrall, 1983). High elevation provenances have reduced threshold temperatures and thus break bud earlier than lower elevation provenances when grown at lower elevations, suggesting adaptation to a shorter growing season (Worrall, 1983).

The goal of this project is to identify Abies species tolerant of the upper midwestern U.S. climate, and promote increased plant diversity. Objectives in this study are to 1) compare the date of budbreak between species, 2) identify differences in the degree of winter injury, and 3) test the hypothesis that midwinter cold hardiness is inversely related to budbreak.

\section{Materials and Methods}

Site locations. More than 1100 trees representing 38 species and hybrids of Abies were part of a true fir species trial initiated at the Kellogg Research Forest (KRF), Augusta, Mich., in early 1991. In 2002 and 2003, about 300 trees representing 17 species and hybrids (Table 1) were transplanted to three locations in Michigan: Clarksville Horticulture Experiment Station, Clarksville(CHES); Horticulture Teaching and Research Center, East Lansing, (HTRC); and Northwest Michigan Horticulture Research Station, Traverse City (NWHRS) (Fig. 1). These three locations along with the KRF represent different climate regions (Table 2 ) in Michigan. Soils at HTRC and NWHRS were loamy sand while soils at CHES and KRF were sandy loam. Trees were dug and ball and burlapped as 60 to $76 \mathrm{~cm}$ root balls in accordance with nursery standards. At least four trees of each species or hybrid were planted at each location with the exception of the HTRC where one to four additional trees of each species were planted when available. Trees were planted at about $4.5 \mathrm{~m}$ intervals in a complete randomized design at each location. In addition, at KRF four trees of each species were selected for further study.

Fertilization. In Spring 2004, sites were fertilized with granular 21-0-0 ammonium sulfate at a rate of about $133 \mathrm{~g}$ per tree, to lower soil 
Table 1. List of Abies species planted at four locations in Michigan.

\begin{tabular}{|c|c|c|c|c|}
\hline Common name & Scientific name & Geographic origin & Elevation $(\mathrm{m})^{z}$ & Latitude $\left({ }^{\circ} \mathrm{N}\right)^{z}$ \\
\hline Ernst fir & A. chensiensis Van Tiegh. & Asia & $2500-3800$ & $25-33$ \\
\hline Needle fir & A. holophylla Maxim. & Asia & $0-1400$ & $33-49$ \\
\hline Nikko fir & A. homolepis Sieb. et Zucc. & Asia & $600-2200$ & $33-38$ \\
\hline Veitch fir & A. veitchii Lindl. & Asia & $1200-3000$ & $33-38$ \\
\hline Balsam fir & A. balsamea (Linn.) Mill. & N. America & $0-1500$ & $38-59$ \\
\hline Cannan fir & A. balsamea var phanerolepis (Fern.) Liu & N. America & $0-1500$ & $38-59$ \\
\hline Noble fir & A. procera Rehd. & N. America & $100-2700$ & $41-48$ \\
\hline Subalpine fir & A. lasiocarpa (Hook.) Nutt. & N. America & $0-3500$ & $32-64$ \\
\hline Nordman fir & A. nordmanniana (Steven) Spach. & Mediterranean & $1000-2200$ & $40-44$ \\
\hline Turkish fir & $\begin{array}{l}\text { A nordmanniana ssp. equi-trojani (Aschers. et Sint. Ex Boiss.) } \\
\text { Coode et Cullen }\end{array}$ & Mediterranean & $1000-2200$ & $40-44$ \\
\hline Fraser $\times$ Nikko hybrid & A. fraseri $\times$ homolepis & N. America/Asia & --- & --- \\
\hline Korean $\times$ Balsam hybrid & A. koreana $\times$ balsamea & N. America/Asia & --- & --- \\
\hline
\end{tabular}

${ }^{2}$ Referenced in Liu, 1971.

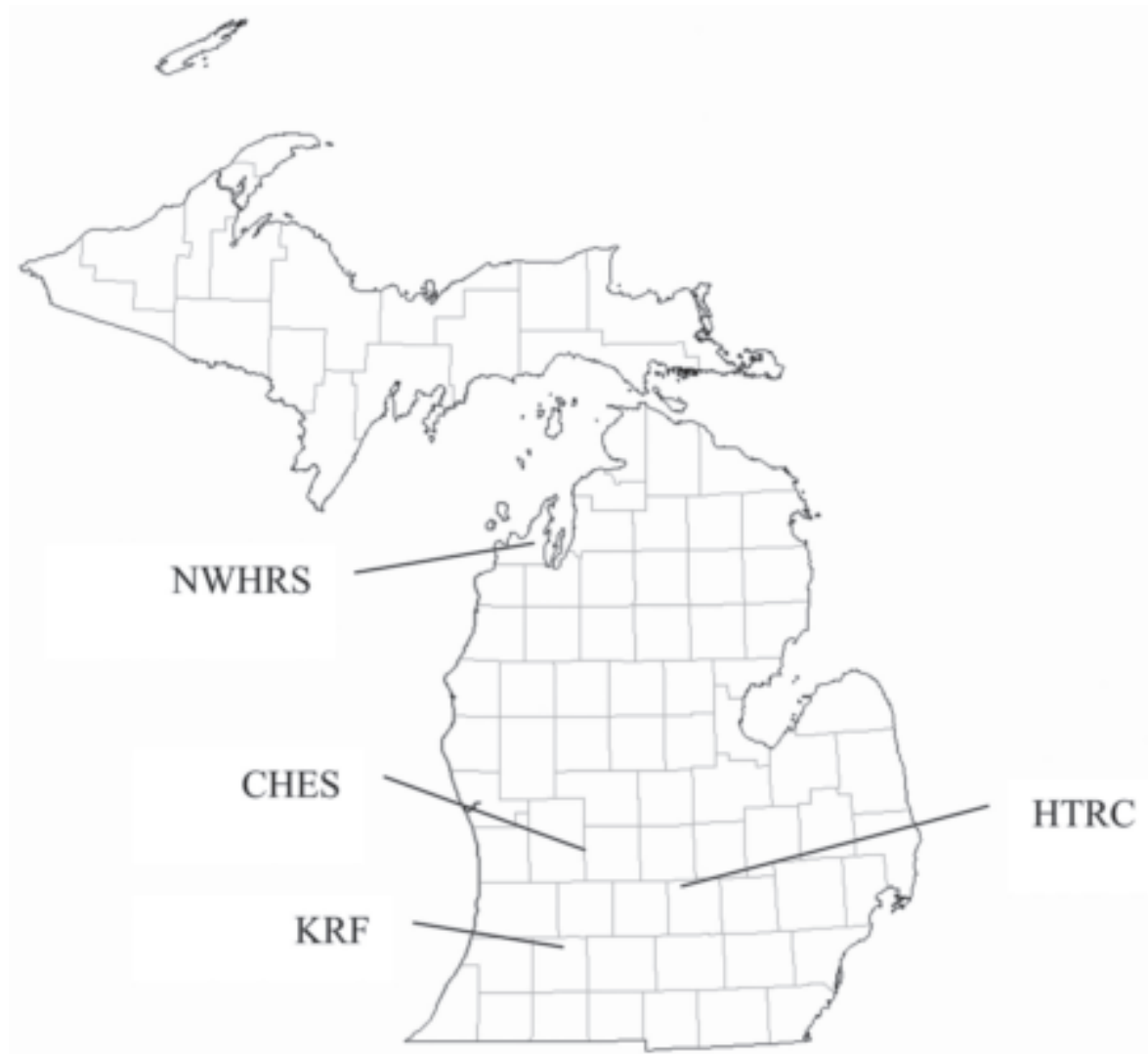

Fig. 1.Location of four Abies trials in Michigan: 1) Kellogg Research Forest (KRF), 2) Clarksville Horticultural Experiment Station (CHES), 3) Horticulture Teaching and Research Center (HTRC), and 4) Northwest Michigan Horticultural Research Station (NWHRS).

$\mathrm{pH}$, and insure that nitrogen was not limiting. Fertilizer was applied at CHES on 29 Apr., at HTRC on 22 Apr., and at NWHRS on 11 May. On 7 July 2004, 46-0-0 urea was applied at CHES at a rate of $91 \mathrm{~g}$ per tree. Trees at KRF were fertilized every fall with $21-0-0$ at $85 \mathrm{~g}$ per tree. Trees exceeding $0.9 \mathrm{~m}$ received $28 \mathrm{~g}$ of fertilizer for each additional $0.3 \mathrm{~m}$ in height.

Budbreak. Beginning 16 Mar. 2004 and 24 Mar. 2005, trees at each of the three outlying sites and the KRF were surveyed for budbreak, considered to have occurred once one shoot broke its bud scale. Trees were inspected weekly until all trees at each location had broken bud. Air temperature was recorded using weather stations located at each site and available for download on the Michigan Automated Weather Network (MAWN) (http://www.agweather.geo.msu.edu/mawn/) website. For each inspection date, growing degree days (GDD) were calculated using a base temperature of $10{ }^{\circ} \mathrm{C}$ (Dickson et al., 2000) and the numerical integration method using the MAWN website.

Frost damage. Temperatures reached -2.2 and $-2.4^{\circ} \mathrm{C}$ on 3 and 4 May 2004 at the KRF after some trees had begun to break bud. Trees were visually rated on 5 May 2004 using the following 0 to 4 scale: $0=$ no shoots damaged, $1=1 \%$ to $25 \%, 2=26 \%$ to $50 \%, 3=51 \%$ to $75 \%$, and $4=76 \%$ to $100 \%$ of shoots damaged. Shoots were considered damaged if they were brown in color or had lost rigidity. All trees in each species block ( $n=7$ to 42 ) were inspected for frost damage, in addition to the four individuals previously selected at random for the budbreak study.

Cold hardiness. Four species were chosen to measure cold hardiness and represent species with early, early-mid, mid-late, and late budbreak groups respectively: A. nephrolepis; A. balsamea var. phanerolepis; A. chensiensi; and $A$. veitchii. Shoots from the current year's growth were collected from three trees of each species at the HTRC. Samples were collected on 13 Dec. 2004, 24 Jan. 2005, and 7 Mar. 2005 with freeze tests beginning 1 to $3 \mathrm{~d}$ later. Twelve samples for each temperature ( 4 species $\times 3$ replications) treatment were laid on moist cheese cloth, covered with aluminum foil, and rolled into bundles. A thermocouple was inserted into the stem of one sample in each bundle to measure stem temperature. Bundles were then placed into a freezer (ScienTemp, Adrian, Mich.) and stored at $2{ }^{\circ} \mathrm{C}$ until the test began. Temperatures were lowered at $3{ }^{\circ} \mathrm{C} \cdot \mathrm{h}^{-1}$ and a bundle was removed at each targeted temperature until completion of the run. A control bundle was kept in a walk-in cooler at $2{ }^{\circ} \mathrm{C}$ where bundles were allowed to thaw following removal from the freezer.

In the 13 Dec. 2004 and 24 Jan. 2005 tests, a bundle was removed at each of the following temperatures: $2,-18,-21,-24,-27,-30,-33$, $-36,-39,-42$, and $-44^{\circ} \mathrm{C}$. In the 7 Mar. 2005 test, a bundle was removed at the following temperatures: $2,-6,-9,-12,-15,-18,-21$, $-24,-27,-30,-33,-36,-39,-42$, and $-44^{\circ} \mathrm{C}$. Bundles were placed in a walk-in cooler and allowed to thaw at $2{ }^{\circ} \mathrm{C}$ for 2 to $3 \mathrm{~d}$ and then placed in a high humidity chamber at room temperature $\left(25^{\circ} \mathrm{C}\right)$ for 4 to $5 \mathrm{~d}$. Then samples were visually rated for needle damage, bud damage, and cambium damage using the following 0 to 2 scale: $0=$ no damage; $1=$ partial browning of the tissue, 2 = dead tissue.

Chlorophyll fluorescence $\left(\mathrm{F}_{\mathrm{v}} / \mathrm{F}_{\mathrm{m}}\right)$ was measured using two needles from every sample in each temperature treatment using a portable 
chlorophyll fluorescence system (plant efficiency analyzer, Hansatech Instruments Ltd., Norfolk, U.K.). Samples were clipped and dark-acclimated for $15 \mathrm{~min}$ before readings were taken.

Statistical analysis. Species effects on budbreak and cold hardiness damage were determined using PROC MIXED (SAS Inc., Cary, N.C.). When significant differences were indicated, means were separated using Tukey's Studentized range test (Sexton, 1998). Species and year effects on the GDD required to budbreak were determined using PROC GLM (SAS Inc.) and means were separated using the Tukey's Studentized range test. Species and location effects on the date of budbreak and GDD required for budbreak were determined by analysis of variance using a fixed effects model:

$y_{\mathrm{ijk}}=\mu+\alpha_{\mathrm{i}}+\gamma_{\mathrm{j}}+\alpha \gamma_{\mathrm{jk}}+\varepsilon_{\mathrm{ijk}}$

where $\mathrm{y}_{\mathrm{ijk}}=$ response of the tree, $\alpha_{\mathrm{i}}$ is the effect of species $i, \gamma_{j}$ is the effect of the location $\mathrm{j}$, and $\varepsilon_{\mathrm{ijk}}$ is the error term. Damage ratings were analyzed using non-parametric measures and with a pairwise comparison of means using the Kruskal-Wallis test (Ott, 1988). Correlation between tissue damage, $\mathrm{F}_{\mathrm{v}} / \mathrm{F}_{\mathrm{m}}$, and the mean date of budbreak were identified using PROC CORR (SAS Inc.).

\section{Results}

Budbreak. The date of budbreak varied with planting location $(P \leq 0.0001)$, species $(P \leq 0.0001)$, and year $(P \leq 0.03)$ (Table 3$)$. We observed variation in budbreak within individual trees as not all buds broke at the same time on a given tree. Budbreak began in mid to late April in both years, lasting between 29 to $49 \mathrm{~d}$ in 2004 and 36 to $49 \mathrm{~d}$ in 2005 depending upon location. Trees at southern sites began and finished breaking bud earlier than northern sites. All trees had broken bud by 17 June 2004 and 9 June 2005 . In both years, $A$. holophylla, $A$. lasiocarpa, $A$. lasiocarpa var. arizonica, and $A$. nephrolepis were among the first to break bud at all four locations, while $A$. veitchii and $A$. homolepis were among the last species to break bud at all four locations.

Growing degree days (GDD) required for budbreak differed among species $(P \leq 0.0001)$, locations $(P \leq 0.0001)$, and years $(P \leq 0.04)$. Trees at the southern locations accumulated GDD faster and required more GDD for budbreak than at northern locations (Table 4). Growing degree day (GDD) accumulation was initially slower in 2005 but by early June GDD accumulation was nearly equal to 2004 . Fewer GDD were required at NWHRS for budbreak than at the other locations.

Species were ranked for budbreak at each location and a strong location: location correlation existed (Table 5) signifying budbreak among species was generally related at each location. Location $\times$ species interaction for both days to budbreak and GDD was significant $(P$ $\leq 0.0001$ ), indicating the rank order of some species changed among locations. For example, A. koreana was in the last group to break bud at CHES, HTRC, and NWHRS while being one of the first species to break bud at KRF. In $A$. koreana $\times$ veitchii and $A$. fraseri $\times$ homolepis, budbreak was not closely related to the parent species, while budbreak for A. koreana $\times$ balsamea was similar to its parents'.

Mean days to budbreak at the HTRC was correlated $\left(R^{2}=0.38, P=0.033\right)$ with average $\mathrm{F}_{\mathrm{v}} / \mathrm{F}_{\mathrm{m}}$ at $-44^{\circ} \mathrm{C}$ (Fig. 2). Trees breaking bud earlier had higher $\mathrm{F}_{\mathrm{v}} / \mathrm{F}_{\mathrm{m}}$ values than trees breaking bud later. Abies chensiensis had the lowest $\mathrm{F}_{\mathrm{v}} / \mathrm{F}_{\mathrm{m}}$ of the species included in the cold hardiness study.

Late frost damage. Late frost damage following the May 2004 freeze was related to the date of budbreak. Trees breaking bud early displayed more damage from the late spring frost than those breaking bud later $(R$ $=0.798, P<0.01)$. At KRF A. holophylla, A. lasiocarpa, A. lasiocarpa var. arizonica, and $A$. nephrolepis displayed a high percent of frost damage in a large number of trees (Fig. 3). In contrast, A. chensiensis, A. fraseri $\times$ homolepis, A. koreana, A. nordmanniana ssp. equi-trojani, and $A$. procera displayed no frost damage. At the time of frost, the following species had not completed budbreak: $A$. fraseri $\times$ homolepis, $A$. homolepis, $A$. koreana, A. koreana $\times$ balsamea, $A$. procera, and $A$. veitchii. In both $A$. homolepis and $A$. veitchii late frost damage occurred in some trees not included in the budbreak survey but inspected for late frost damage.

Cold hardiness. Cold hardiness varied among species and by test date. Chlorophyll fluorescence values declined with decreasing temperatures $(P \leq 0.001)$. Chlorophyll fluorescence $\left(\mathrm{F}_{v} / \mathrm{F}_{\mathrm{m}}\right)$ values decreased as temperatures were lowered during controlled freeze tests in $A$. chensiensis and $A$. veitchii but remained constant in A. balsamea var. phanerolepis and A. nephrolepis as temperatures reached $-44^{\circ} \mathrm{C}$. At $-44{ }^{\circ} \mathrm{C}, \mathrm{F} / \mathrm{F}$ differed among species for tests during December $2004(P \leq 0.002)$ and January $2005(P \leq 0.001)$, but not March 2005 $(P=0.10)$ (Table 6$)$. Needle damage differed among species at $-44{ }^{\circ} \mathrm{C}$ in all tests $(P \leq 0.05)$. Needle damage was greatest in $A$. chensiensis in all tests. Visible damage to needles, stem tissue, and buds was highly correlated ( $P<$ 0.001 ) with a decline in $\mathrm{F} / \mathrm{F}_{\mathrm{m}}$ values (Table 7). Damage to stem tissue and buds did not differ $(P>0.05)$ among species on any test date. Damage to needles, stem tissue, and buds were highly correlated $(P<0.001)$ with a decline in $\mathrm{F}_{\mathrm{v} / \mathrm{m}} \mathrm{F}_{\mathrm{m}}$ values (Table 7).

Table 2. Thirty-year climate summary and USDA plant hardiness zones for four Abies planting sites in Michigan.

\begin{tabular}{|c|c|c|c|c|c|c|}
\hline Location & $\begin{array}{c}\text { Avg } \\
\text { January } \\
\text { low } \\
\left({ }^{\circ} \mathrm{C}\right)^{\mathrm{z}}\end{array}$ & $\begin{array}{l}\text { Avg } \\
\text { July } \\
\text { high } \\
\left({ }^{\circ} \mathrm{C}\right)^{z}\end{array}$ & $\begin{array}{c}\text { Avg } \\
\text { annual } \\
\text { precipitation } \\
(\mathrm{cm})^{\mathrm{z}}\end{array}$ & $\begin{array}{c}\text { Avg } \\
\text { annual } \\
\text { snowfall } \\
(\mathrm{cm})^{\mathrm{z}}\end{array}$ & $\begin{array}{c}\text { Growing } \\
\text { season } \\
{(\text { days })^{z}}^{2}\end{array}$ & $\begin{array}{c}\text { USDA } \\
\text { hardiness } \\
\text { zone }^{y}\end{array}$ \\
\hline$\overline{\text { CHES }^{x}}$ & -10 & 28 & 90.7 & 145 & 147 & $5 B$ \\
\hline $\mathrm{HTRC}^{\mathrm{w}}$ & -11 & 28 & 78.5 & 99 & 150 & $5 \mathrm{~A}$ \\
\hline $\mathrm{KRF}^{\mathrm{v}}$ & -9 & 28 & 89.4 & 135 & 149 & $5 B$ \\
\hline $\mathrm{NWHRS}^{\mathrm{u}}$ & -10 & 27 & 85.1 & 244 & 135 & $5 B$ \\
\hline
\end{tabular}

"Illinois Dept. of Nat. Res., 2005.

yUSDA Plant Hardiness Map, 1990.

${ }^{x}$ Clarksville Horticulture Experiment Station (CHES), Clarksville, Mich.

whorticulture Teaching and Research Center (HTRC), East Lansing, Mich.

'Kellogg Research Forest (KRF), Augusta, Mich.

"Northwest Michigan Horticulture Research Station (NWHRS), Traverse City, Mich. 
when the last tree broke bud than at KRF, which perhaps can explain the difference in the GDD required for budbreak. In P. menziesii var. menziesii (Mirb.) Franc. populations from regions with similar winter temperatures, trees from regions with the largest moisture deficit broke bud earlier than the average (Campbell and Sugano, 1979). This suggests that trees from regions frequented by summer drought break bud early in the spring to complete stem elongation and set bud before summer drought conditions begin (Kaya et al., 1994). Both A. koreana and A. veitchii, two of the last species to break bud in this study, are native to regions with ample summer precipitation (Farjon, 1990) so perhaps their late budbreak is an adaptive response to a mild climate and adequate summer precipitation.

Within species, provenances can vary greatly in time of budbreak(Hansen and Larsen,
2004; Scholz and Stephen, 1982; Worral, 1983) and cold hardiness levels (Dolnicki and Kraj, 1998; Eiga and Sakai, 1984, 1987, Xie and Ying, 1993). One of the limitations of the current study is that provenance information for each species is unknown. Moreover, it is unknown if the parent trees of the hybrids were from the same provenance as the pure species included in this study. For example, the A. veitchii parent of the A. koreana $\times$ veitchii hybrid is not necessarily from the same seed source as the pure $A$. veitchii included in this study, which could explain some of the inconsistencies in the budbreak between the parents and their hybrids. Also, variation within a species is not accurately represented because each species is represented by a single provenance.

Chlorophyll fluorescence $\left(\mathrm{F}_{\mathrm{v}} / \mathrm{F}_{\mathrm{m}}\right)$ was a good indicator of cold injury during controlled freeze tests as $F_{v} / F_{m}$ values declined with decreasing temperatures. These results paralleled increasing needle, stem, and bud damage, which is consistent with previous studies (Adams and Perkins, 1993; Binder and Fielder, 1996). Cold hardiness between different plant organs differs in the temperature at which damage occurs (Sakai, 1982). The temperature where damage occurred was different for buds, stems, and needles. However, damage variables and $\mathrm{F}_{\mathrm{v}} / \mathrm{F}_{\mathrm{m}}$ values were strongly correlated suggesting that while the temperatures that damage different organs may vary, relative cold hardiness is related (Table 7).

Many studies show differences in cold hardiness among species and provenances (Eiga and Sakai, 1984, 1987; Sakai, 1982; Xie and Ying, 1993). As expected, trees included in the cold hardiness study also varied in the temperature at which they displayed damage

Table 3. Budbreak date of 17 Abies species grown at four locations in Michigan in 2004 and 2005.

\begin{tabular}{|c|c|c|c|c|c|c|c|c|}
\hline \multirow[b]{2}{*}{ Species } & \multicolumn{4}{|c|}{2004} & \multicolumn{4}{|c|}{2005} \\
\hline & CHES $^{x}$ & HTRC $^{w}$ & $\mathrm{KRF}^{\mathrm{v}}$ & NWHRS $^{u}$ & CHES & HTRC & KRF & NWHRS \\
\hline A. nephrolepis & April $20 \mathrm{a}^{\mathrm{z}}$ & April 24 abc & April 22 a & May 4 a & April $20 \mathrm{a}$ & April $20 \mathrm{a}$ & April $20 \mathrm{a}$ & April 28 a \\
\hline A. lasiocarpa var. arizonica & April 22 a & April $23 \mathrm{ab}$ & April 22 a & May 4 a & April 19 a & April 20 a & April 20 a & May $1 \mathrm{ab}$ \\
\hline A. holopylla & April 23 a & April 21 a & April 22 a & May $6 \mathrm{ab}$ & April 20 a & April 20 a & April 20 a & May $3 \mathrm{ab}$ \\
\hline A. lasiocarpa & April $29 \mathrm{ab}$ & April $22 \mathrm{ab}$ & April 22 a & May 6ab & April 30 abcd & April 26 ab & April $20 \mathrm{a}$ & April 29 a \\
\hline A. balsamea & May 2 abc & May 1 abc & $\mathrm{NR}^{\mathrm{y}}$ & May $10 \mathrm{ab}$ & April $24 \mathrm{ab}$ & May 2 abc & April 26 abc & May 10 abc \\
\hline A. koreana $\times$ veitchii & May 3 abc & May 3 bcde & April 26 ab & May 17 abcde & May 2 abcd & May 5 bcd & April 22 ab & May 18 abc \\
\hline A. bal. var. phanerolepis & May 5 abc & May 3 bcde & $\mathrm{NR}^{\mathrm{y}}$ & May 15 abcde & April 28 abcd & May 5 bcd & April 27 abc & May 15 abc \\
\hline A. nordmanniana & May 5 abc & May 5 cdef & $\mathrm{NR}^{\mathrm{y}}$ & $\mathrm{NR}^{\mathrm{y}}$ & April 27 abc & May 9 bcde & May 4 abcd & $\mathrm{NR}^{\mathrm{y}}$ \\
\hline A. koreana $\times$ balsamea & May 5 abc & May 26 i & May 3 abc & June $4 \mathrm{e}$ & May 6 abcd & May 26 fg & May 2 abc & May 25 bc \\
\hline A. fraseri $\times$ homolepis & May 12 bc & May 7 defg & May 5 abc & May 25 bcde & May 9 abcd & May 9 bcde & May 8 bcde & May 18 abc \\
\hline A. procera & May 12 bc & May 12 defgh & May 7 bc & May 13 abcd & May 9 abcd & May 18 defg & May 10 cde & May $30 \mathrm{c}$ \\
\hline A. nord. ssp. equi-trojani & May 12 bc & May 14 efgh & May 5 abc & May 27 cde & May 1 abcd & May 12 cdef & May 8 bcde & May 22 abc \\
\hline A. chensiensis & May 14 bc & May 12 defgh & May 3 abc & May 13 abcd & May 10 bcd & May 10 bcde & May 10 cde & May 17 abc \\
\hline A. homolepis & May $16 \mathrm{c}$ & May 18 ghi & May 12 c & May 20 abcde & May $18 \mathrm{~d}$ & May 24 efg & May 20 de & May 25 bc \\
\hline A. fraseri & May $17 \mathrm{c}$ & May 16 fghi & $\mathrm{NR}^{\mathrm{y}}$ & May 29 cde & May 10 abcd & May 15 cdefg & May 11 cde & May 20 abc \\
\hline A. koreana & May 19 c & May 22 hi & May 2 abc & May 27 cde & May $17 \mathrm{~cd}$ & May $25 \mathrm{fg}$ & May 10 cde & May $20 a b c$ \\
\hline A. veitchii & May $19 \mathrm{c}$ & May 22 hi & May $14 \mathrm{c}$ & June 3 de & May $17 \mathrm{~cd}$ & May $28 \mathrm{~g}$ & May 24 e & June $1 \mathrm{c}$ \\
\hline
\end{tabular}

${ }^{\mathrm{z}}$ Means within columns followed by the same letter were not statistically different, $\alpha=0.05$, Tukey Studentized range test.

y No records were available for trees listed as NR.

${ }^{x}$ Clarksville Horticulture Experiment Station (CHES), Clarksville, Mich.

${ }^{\text {wH}}$ Horticulture Teaching and Research Center (HTRC), East Lansing, Mich.

'Kellogg Research Forest (KRF), Augusta, Mich.

"Northwest Michigan Horticulture Research Station (NWHRS), Traverse City, Mich.

Table 4. Mean growing degree days required before budbreak in 17 Abies species grown at four locations in Michigan in 2004 and 2005.

\begin{tabular}{|c|c|c|c|c|c|c|c|c|}
\hline \multirow[b]{2}{*}{ Species } & \multicolumn{4}{|c|}{2004} & \multicolumn{4}{|c|}{2005} \\
\hline & $\mathrm{CHES}^{\mathrm{x}}$ & $\mathrm{HTRC}^{\mathrm{w}}$ & $\mathrm{KRF}^{\mathrm{v}}$ & NWHRS $^{u}$ & CHES & HTRC & KRF & NWHRS \\
\hline A. nephrolepis & $114 \mathrm{a}^{\mathrm{z}}$ & $128 \mathrm{a}$ & $150 \mathrm{a}$ & $81 \mathrm{a}$ & $153 \mathrm{a}$ & $148 \mathrm{a}$ & $176 \mathrm{a}$ & $102 \mathrm{a}$ \\
\hline A. lasiocarpa var. arizonica & $119 \mathrm{ab}$ & $124 \mathrm{a}$ & $150 \mathrm{a}$ & $95 \mathrm{ab}$ & $153 \mathrm{a}$ & $148 \mathrm{a}$ & $176 \mathrm{a}$ & $102 \mathrm{a}$ \\
\hline A. holophylla & $122 \mathrm{ab}$ & $117 \mathrm{a}$ & $150 \mathrm{a}$ & $83 \mathrm{a}$ & $153 \mathrm{a}$ & $148 \mathrm{a}$ & $176 \mathrm{a}$ & $106 \mathrm{a}$ \\
\hline A. lasiocarpa & $170 \mathrm{abc}$ & $123 \mathrm{a}$ & $150 \mathrm{a}$ & $110 \mathrm{ab}$ & $163 \mathrm{ab}$ & $175 \mathrm{ab}$ & $176 \mathrm{a}$ & $113 \mathrm{a}$ \\
\hline A. nordmanniana & $182 \mathrm{abcd}$ & $209 \mathrm{abc}$ & $\mathrm{NR}^{\mathrm{y}}$ & $\mathrm{NR}^{\mathrm{y}}$ & $159 \mathrm{a}$ & $204 \mathrm{ab}$ & $227 \mathrm{ab}$ & $\mathrm{NR}^{\mathrm{y}}$ \\
\hline A. bal. var phanerolepis & $193 \mathrm{abcd}$ & $179 \mathrm{ab}$ & $\mathrm{NR}^{\mathrm{y}}$ & $157 \mathrm{abc}$ & $162 \mathrm{ab}$ & $180 \mathrm{ab}$ & $201 \mathrm{a}$ & $162 \mathrm{abc}$ \\
\hline A. koreana $\times$ veitchii & 198 abcde & $179 \mathrm{ab}$ & $163 \mathrm{a}$ & $169 \mathrm{abc}$ & $197 \mathrm{abc}$ & $180 \mathrm{ab}$ & $177 \mathrm{a}$ & $181 \mathrm{abc}$ \\
\hline A. koreana $\times$ balsamea & 223 abcdef & $447 \mathrm{f}$ & $220 \mathrm{ab}$ & $286 \mathrm{c}$ & $218 \mathrm{abc}$ & 310 de & $224 \mathrm{a}$ & $242 \mathrm{abc}$ \\
\hline A. balsamea & 226 abcdef & $167 \mathrm{a}$ & $\mathrm{NR}^{\mathrm{y}}$ & $114 \mathrm{ab}$ & $158 \mathrm{a}$ & $193 \mathrm{ab}$ & $181 \mathrm{a}$ & $142 \mathrm{ab}$ \\
\hline A. nord. ssp. equi-trojani & 269 bcdef & 310 cde & $221 \mathrm{ab}$ & 214 abc & $180 \mathrm{abc}$ & 231 abcd & $231 \mathrm{ab}$ & $206 \mathrm{abc}$ \\
\hline A. fraseri $\times$ homolepis & 270 bcdef & $223 \mathrm{abc}$ & $246 \mathrm{ab}$ & $201 \mathrm{abc}$ & $210 \mathrm{abc}$ & $208 \mathrm{abc}$ & $231 \mathrm{ab}$ & $198 \mathrm{abc}$ \\
\hline A. procera & 272 bcdef & $285 \mathrm{bcd}$ & $247 \mathrm{ab}$ & $146 \mathrm{abc}$ & $223 \mathrm{abc}$ & $252 \mathrm{bcd}$ & $251 \mathrm{abc}$ & $284 \mathrm{bc}$ \\
\hline A. chensiensis & 292 cdef & $285 \mathrm{bcd}$ & $208 \mathrm{ab}$ & $146 \mathrm{abc}$ & $237 \mathrm{abc}$ & 219 abcd & $251 \mathrm{abc}$ & $168 \mathrm{abc}$ \\
\hline A. homolepis & 317 cdef & 355 def & $325 \mathrm{~b}$ & $184 \mathrm{abc}$ & $276 \mathrm{c}$ & 306 cde & $324 \mathrm{bc}$ & $219 a b c$ \\
\hline A. fraseri & 331 def & 325 cde & $\mathrm{NR}^{\mathrm{y}}$ & $220 \mathrm{abc}$ & $220 \mathrm{abc}$ & 248 bcd & $270 \mathrm{abc}$ & $189 \mathrm{abc}$ \\
\hline A. koreana & 347 ef & 403 ef & $233 \mathrm{ab}$ & $249 \mathrm{bc}$ & $264 \mathrm{bc}$ & $310 \mathrm{de}$ & $258 \mathrm{abc}$ & $194 \mathrm{abc}$ \\
\hline A. veitchii & $364 \mathrm{f}$ & 396 def & 342 b & $299 \mathrm{c}$ & $266 \mathrm{c}$ & $351 \mathrm{e}$ & $348 \mathrm{c}$ & $324 \mathrm{c}$ \\
\hline
\end{tabular}

${ }^{\mathrm{z}}$ Means within columns followed by the same letter were not statistically different, $\alpha=0.05$.

${ }^{y}$ No records available for trees listed as NR.

${ }^{x}$ Clarksville Horticulture Experiment Station (CHES), Clarksville, Mich.

wHorticulture Teaching and Research Station (HTRC), East Lansing, Mich.

vellogg Research Forest (KRF), Augusta, Mich.

Northwest Michigan Horticulture Research Station (NWHRS), Traverse City, Mich.

tBase temperature $10{ }^{\circ} \mathrm{C}$. 


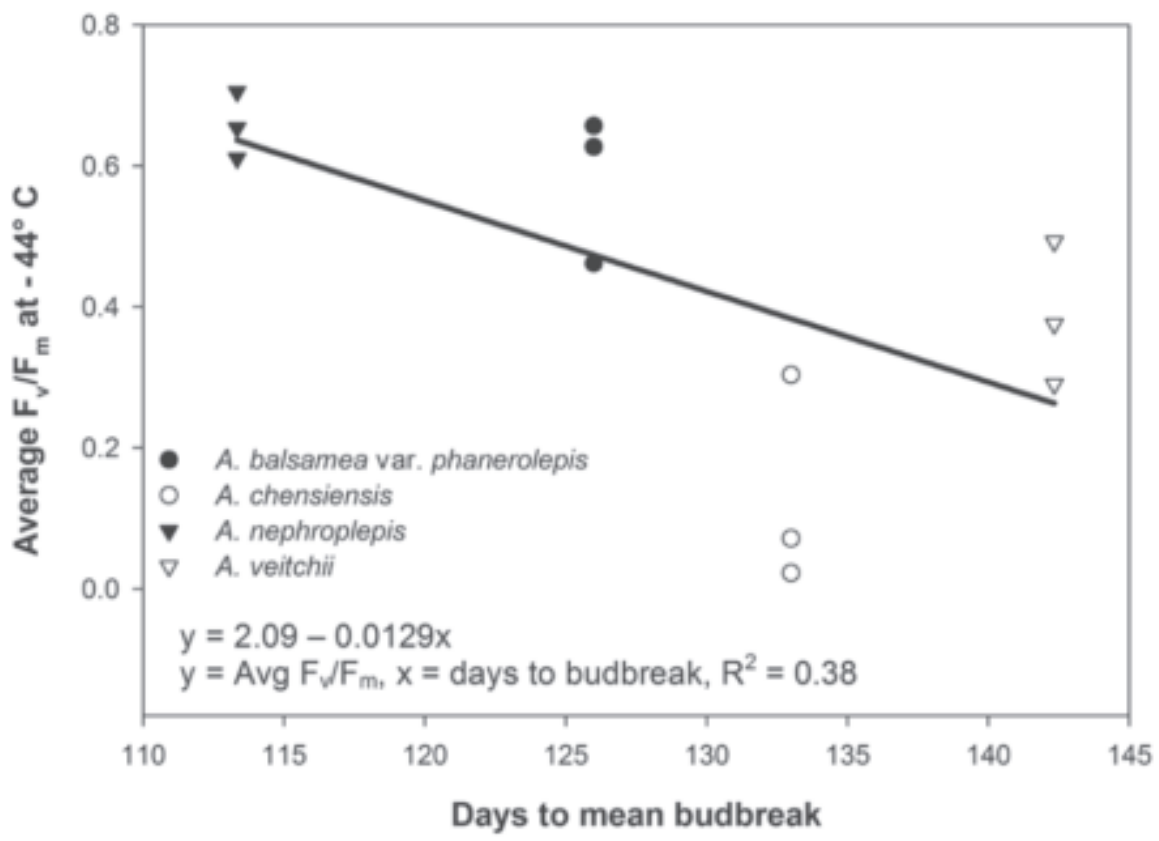

Fig. 2. Comparison of average chlorophyll fluorescence $\left(\mathrm{F}_{\mathrm{v}} / \mathrm{F}_{\mathrm{m}}\right)$ at $-44{ }^{\circ} \mathrm{C}$ and days to mean budbreak in four Abies species growing at the Horticulture Teaching and Research Center in December 2004, January 2005, and March 2005.

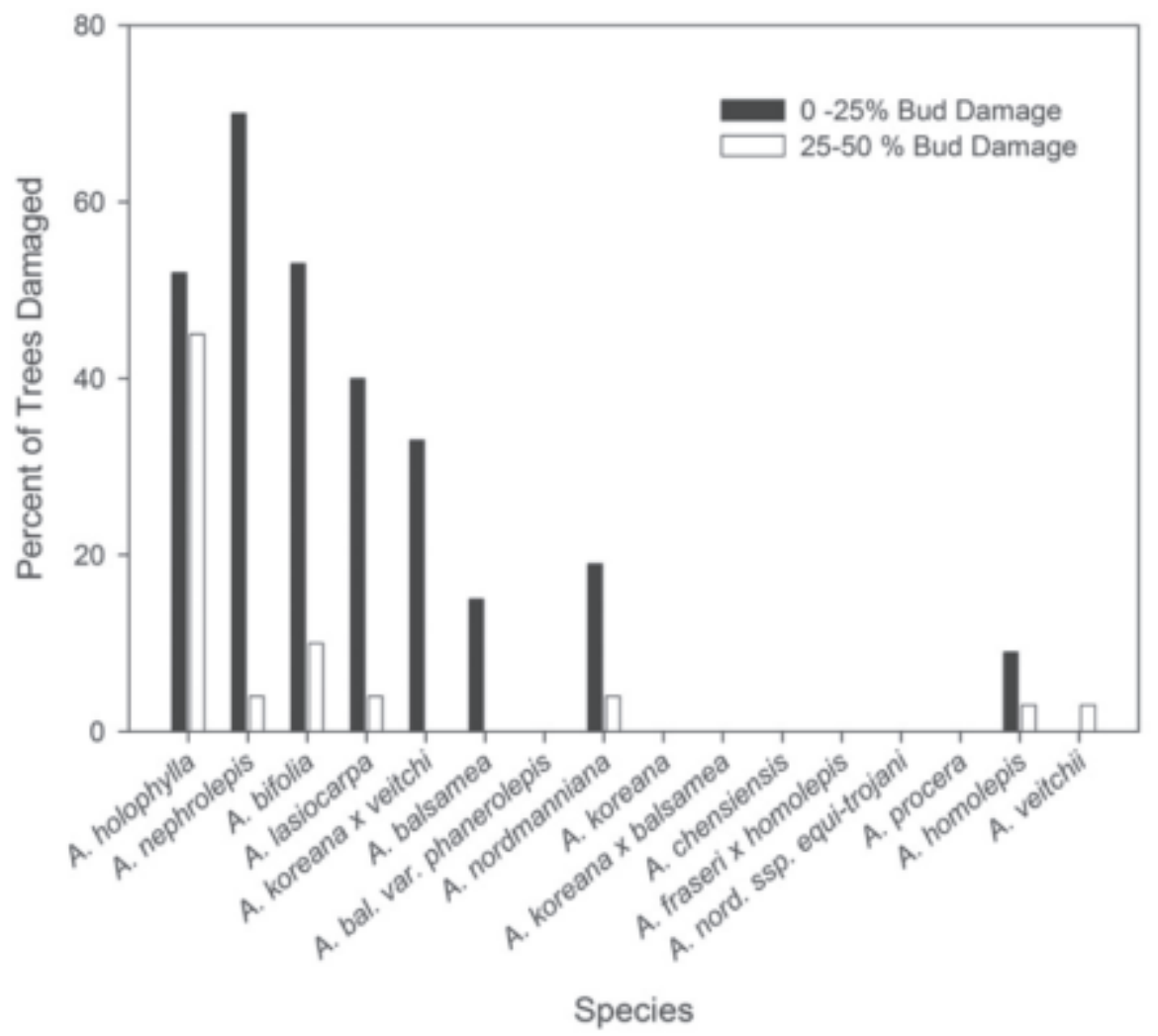

Fig. 3. Frost damage to recently emerged shoots at the Kellogg Research Forest, 5 May 2004.

to freezing temperatures. One limitation of the current study was the inability of the programmable freezer to be lowered beyond $-44{ }^{\circ} \mathrm{C}$. From a practical stand point, this is near to the lowest annual temperatures in the coldest regions of the upper midwestern U.S. In most years, species showing no signs of damage should be able to survive most winters if given the necessary time to acclimate.
During the fall, the degree of cold hardiness in trees gradually increases, reaches a maximum during midwinter, and gradual declines (Ritchie, 2003). Bud damage in the March test indicates internal development processes related to budbreak may have begun, and warmer temperatures likely reduced cold hardiness levels leading to increased freeze damage. Needle damage ratings were the lowest in January (Table 6). Typically January temperatures were the lowest so more conditioning lead to greater cold hardiness. Increased damage in December and March was likely due to incomplete acclimation and the start of deacclimation leading to less cold hardiness. Stem damage ratings did not differ among species suggesting cambium tissue was adequately insulated at $-44^{\circ} \mathrm{C}$, the lowest temperature possible in our controlled freeze test. Chlorophyllfluorescence $\left(\mathrm{F}_{\mathrm{v}} / \mathrm{F}_{\mathrm{m}}\right)$ declined progressively between each test suggesting that repairs to cold damage did not begin until growth began again in the spring. Chlorophyll fluorescence $\left(\mathrm{F}_{\mathrm{v}} / \mathrm{F}_{\mathrm{m}}\right)$ at $-44^{\circ} \mathrm{C}$ differed significantly among species in December and January, but not March.

Other factors being equal, trees from colder regions are cold hardy at lower temperatures (Sakai, 1982) and break bud earlier in a common site, due to a reduced chilling and thermal time requirement, than trees from warmer regions. Worral (1983) suggests this may be an adaptation allowing trees to complete their growth before fall frosts in cold regions with short growing seasons. In the present study, date of budbreak and $\mathrm{F}_{\mathrm{v}} / \mathrm{F}_{\mathrm{m}}$ readings at -44 ${ }^{\circ} \mathrm{C}$ were strongly correlated for the individual trees included in the cold hardiness experiment. Trees with maximum cold hardiness levels were among the first species to break bud in the spring while species with reduced cold hardiness were among the last (Fig. 2), suggesting trade-offs between midwinter cold hardiness and the GDD required to break bud.

In summary, species varied in their tolerance of freezing temperatures and in the date they broke bud. Strong correlations existed between the temperatures at which different plant tissues showed visual signs of damage. Species that were among the first to break bud in the spring withstood colder winter temperatures than trees breaking bud later. Species breaking bud early in the spring were more likely to be damaged by late spring frosts. Budbreak should continue as an important selection criterion for conifer species introduced to the landscape and Christmas tree industries in the upper Midwest. Species such as A. homolepis, $A$. koreana, and $A$. veitchii were among the last species to break bud at all locations and should be considered for future introduction. Additional studies should focus on identifying provenances with late budbreak and adequate cold hardiness for species with desirable ornamental characteristics such as A. lasiocarpa

Table 5. Pearson correlation coefficients for budbreak of 17 Abies species at four locations in Michigan.

\begin{tabular}{lccc}
\hline Location & HTRC $^{y}$ & KRF $^{x}$ & NWHRS $^{*}$ \\
\hline CHES $^{\mathrm{z}}$ & $0.71^{* * * *}$ & $0.61^{* * * *}$ & $0.53^{* * *}$ \\
HTRC & & $0.60^{* * *}$ & $0.71^{* * *}$ \\
KRF & & & $0.58^{* * *}$ \\
\hline
\end{tabular}

${ }^{2}$ Clarksville Horticulture Experiment Station (CHES), Clarksville, Mich.

${ }^{y}$ Horticulture Teaching and Research Center(HTRC), East Lansing, Mich.

${ }^{x}$ Kellogg Research Forest (KRF), Augusta, Mich. "Northwest Michigan Horticulture Research Station (NWHRS), Traverse City, Mich.

${ }^{* * *}$ Significant at $P \leq 0.0001$. 
Table 6. Mean chlorophyll fluorescence $\left(\mathrm{F}_{\mathrm{v}} / \mathrm{F}_{\mathrm{m}}\right)$ values and needle damage ratings of four Abies species following controlled freeze tests to $-44^{\circ} \mathrm{C}$.

\begin{tabular}{lccccccc}
\hline & \multicolumn{3}{c}{$\mathrm{F}_{\mathrm{v}} / \mathrm{F}_{\mathrm{m}}$} & & \multicolumn{3}{c}{ Needle damage } \\
\cline { 2 - 3 } Species & December $^{\mathrm{*}^{*}}$ & January $^{\mathrm{w}^{*}}$ & March $^{v}$ & & December $^{*}$ & January $^{*}$ & March $^{*}$ \\
\hline A. bal. var. phanerolepis & $0.627 \mathrm{a}^{\mathrm{z}}$ & $0.657 \mathrm{a}$ & 0.462 & & $1.0 \mathrm{a}^{\mathrm{yu}}$ & $0.0 \mathrm{a}$ & $0.3 \mathrm{ab}$ \\
A. nephrolepis & $0.611 \mathrm{a}$ & $0.654 \mathrm{a}$ & 0.705 & & $1.0 \mathrm{a}$ & $0.0 \mathrm{a}$ & $0.0 \mathrm{a}$ \\
A. veitchii & $0.375 \mathrm{a}$ & $0.492 \mathrm{a}$ & 0.291 & & $1.7 \mathrm{a}$ & $0.7 \mathrm{a}$ & $1.7 \mathrm{bc}$ \\
A. chensiensis & $0.022 \mathrm{~b}$ & $0.071 \mathrm{~b}$ & 0.304 & & $2.0 \mathrm{~b}$ & $2.0 \mathrm{~b}$ & $2.0 \mathrm{c}$ \\
\hline
\end{tabular}

${ }^{z}$ Means within a column followed by the same letter were not significantly different, $\alpha=0.05$, Tukey studentized range test.

${ }^{y}$ Means within a column followed by the same letter were not significantly different, $\alpha=0.05$, KruskalWallis.

${ }^{x}$ Shoots collected on 13 Dec. 2004.

"Shoots collected on 24 Jan. 2005.

'Shoots collected on 7 Mar. 2005.

"Rating scale $0=$ no damage, $1=$ partial browning of the tissue, $2=$ dead tissue.

*Significant at $P \leq 0.05$ and indicates significant species effects for controlled freeze test that month.

Table 7. Pearson's correlation coefficient for needle, stem, and bud damage and chlorophyll fluorescence $\left(\mathrm{F}_{v} / \mathrm{F}_{\mathrm{m}}\right)$ in four Abies species growing at the Horticulture Teaching and Research Center in March 2005 following controlled freeze test.

\begin{tabular}{llcr}
\hline & $\begin{array}{c}\text { Needle } \\
\text { damage }\end{array}$ & $\begin{array}{c}\text { Stem } \\
\text { damage }\end{array}$ & $\begin{array}{c}\text { Bud } \\
\text { damage }\end{array}$ \\
\hline $\mathrm{F}_{\mathrm{V}} / \mathrm{F}_{\mathrm{m}}$ & $-0.60^{* * *}$ & $-0.69^{* * * *}$ & $-0.46^{* * * *}$ \\
Needle damage & & $0.77^{* * *}$ & $0.65^{* * *}$ \\
Stem damage & & & $0.68^{* * *}$ \\
\hline
\end{tabular}

*** Significant at $P \leq 0.0001$.

and A. lasiocarpa var. arizonica.

\section{Literature Cited}

Adams, G.T. and T.D. Perkins. 1993. Assessing cold tolerance in Picea using chlorophyll fluorescence. Environ. Expt. Bot. 33:377-382.

Binder, W.D. and P. Fielder. 1996. Chlorophyll fluorescence as an indicator of frost hardiness in white spruce seedlings from different latitudes. New For. 11:233-253.

Björkman, O. and B. Demming. 1987. Photo yield of $\mathrm{O}_{2}$ evolution and chlorophyll fluorescence characteristics at $77 \mathrm{~K}$ among vascular plants of diverse origins. Planta 170:489-504.

Campbell, R.K. and A.I. Sugano. 1979. Genecology of bud-burst phenology in douglas-fir: Response to flushing temperature and chilling. Bot. Gaz. 140:223-231.

Cregg, B.M., M.W. Duck, C.M., Rios, D.B. Rowe, and M.R. Koelling. 2004. Chlorophyll fluorescence and needle chlorophyll concentration of fir (Abies sp.) seedlings in response to $\mathrm{pH}$. HortScience 39:1121-1125.

Dickson, R.L., G.B. Sweet, and N.D. Mitchell. 2000. Predicting Pinus radiata female strobilus production for seed orchard site selection in New Zealand. For. Ecol. Mgt. 133:197-215.

Dolnicki, A. and W. Kraj. 1998. Dynamics of frost resistance in various provenances of Abies grandis Lindl. Acta Societatis Botanicorum
Poloniae. 67:51-58.

Eiga, S. and A. Sakai. 1984. Altitudinal variation in freezing resistance of saghalien fir (Abies sachalinensis). Can. J. Bot. 62:156-160.

Eiga, S. and A. Sakai. 1987. Regional variation in cold hardiness of sakhalin fir (Abies sachalinensis Mast.) in Hokkaido, Japan. In: P.H. Li (ed.). Plant cold hardiness. Liss, New York.

Farjon, A. 1990. Pinaceae drawings and descriptions of the genera Abies, Cedrus, Psudolarix, Keteleeria, Nothotsuga, Tsuga, Cathaya, Pseudotsuga, Larix, and Picea. Champaign, Ill.

Gordon-Kamm, W.J. 1980. Freezing tolerance of several conifers in a western Washington forest community. MS thesis. Western Wash. Univ. Bellingham.

Guehl, J.M, G. Aussenac, J. Bouachrine, R. Zimmerman, J.M. Pennes, A. Ferhi, and P. Grieu. 1991. Sensitivity of leaf gas exchange to atmospheric drought, soil drought, and water-use efficiency in some Mediterranean Abies species. Can. J. For. Res. 21:1507-1515.

Hansen, J.K. and J. B. Larsen. 2004. European silver fir (Abies alba Mill.) provenances from Calabria, southern Italy: 15-year results from Danish provenance field trials. Euro. J. For. Res. 123:127-138.

Hansen, O.K., U.B. Nielsen, Ø.M. Edvardsen, B. Skúlason, and J. Skage. 2004. Nordic provenance trials with Abies lasiocarpa and Abies lasiocarpa var. arizonica: Three-year results. Scand. J. For. Res. 19:112-126.

Howe, G.T., S.N. Aitken, D.B. Neale, K.D., Jermstad, N.C. Wheeler, and T.H.H. Chen. 2003. From genotype to phenotype: Unraveling the complexities of cold adaptation in forest trees. Can. J. Bot. 81:1247-1266.

Illinois Department of Natural Resources. 2005. Midwest Regional Climate Center. Champaign, Ill. 20 June 2005. http://sisyphus.sws.uiuc. edu/index.html.

Kaya, Z., W.T. Adams, and R. K. Campbell. 1994. Adaptive significance of intermittent shoot growth in douglas-fir seedlings. Tree Physiol. 14:1277-1289.

Langlet, O. 1963. Patterns and terms of intra-specific ecological variability. Nature 200:347-348.

Lantagne, D. and M. Koelling. 2004. Tree planting in Michigan. MSU Ext. Publ.http://forestry.msu. edu/extension/ExtDocs/treeplnt.htm.

Leege, T. 2002. An evaluation of exotic true firs in the inland northwest. Amer. Christmas Tree J. 46:49-51.

Liu, T.S. 1971. A monograph of the genus Abies. Taipei, Taiwan.

McCullough, D.G., S.A. Katovich, M.E. Ostry, and J. Cummings-Carlson. 1998. Christmas tree pest manual. 2nd ed. Mich. State Ext. Bul. E-2676.

Morgenstern, E.K. 1978. Range-wide genetic variation of black spruce. Can. J. For. Res. 8:463-473.

Ott, L. 1988. An introduction to statistical methods and data analysis. PWS-Kent, Boston.

Owston, P.W. and T.T. Kozlowski. 1981. Growth and cold hardiness of container grown douglas-fir, noble fir, and sitka spruce seedlings in simulated greenhouse regimes. Can. J. For. Res. 11:465-474.

Partanen, J., V. Koski, and H. Hänninen. 1998. Effects of photoperiod and temperature on the timing of bud burst in norway spruce (Picea abies). Tree Physiol. 18:811-816.

Perry, T.O. and W.C. Wu. 1960. Genetic variation in the winter chilling requirement for date of dormancy break for Acer rubrum. Ecology 41:790-794.

Ritchie, G.A. 2003. Root physiology and phenology: the key to transplanting success. In: L.E. Riley, R.K. Dumroese, and T.D. Landis (tech. coords.). National proceedings: Forest and conservation nursery associations-2002. USDA For. Serv., Rocky Mountain research station, Ogden, Utah, Proceedings RMRS-P-28:98-104.

Sakai, A. 1982. Extraorgan freezing of primordial shoots of winter buds of conifers, p. 199-209. In P.H. Li and A. Sakai (eds.). Plant cold hardiness and freezing stress mechanisms and crop implications. vol. 2. Academic Press, New York.

Scholz, F. and B.R. Stephan. 1982. Growth and reaction to drought of 43 Abies grandis provenances in a greenhouse study. Silvae Genet. 31:27-35.

Saxton, A.M. 1998. A macro for converting mean separation output to letter groupings in Proc Mixed, p. 1243-1246. In: Proc. 23rd SAS users group Intl. SAS Institute, Nashville, Tenn., 22-25 Mar.

U.S. Department of Agriculture. Plant hardiness zone map. 1990. USDA Misc. Publ. 1475.

van der Kamp, B.J. and J. Worrall. 1990. An unusual case of winter bud damage in British Columbia interior conifers. Can. J. For. Res. 20:1640-1647.

Worrall, J. 1983. Temperature-Bud-burst relationships in amabilis and subalpine fir provenance tests replicated at different elevations. Silvae Genet. 32:203-209.

Xie, C.Y. and C.C. Ying. 1993. Geographic variation of grand fir (Abies grandis) in the Pacific coast region: 10-year results from a provenance trial. Can. J. For. Res. 23:1065-1072.

Yordanov, I. 1992. Response of photosynthetic apparatus to temperature stress and molecular mechanisms of its adaptation. Photosynthetica 26:517-531. 